\title{
Impact of Financing Sources on Innovation and Firm Productivity: Evidence from South Asia
}

\author{
Ms. Fatima Amin ${ }^{1 *}$, Dr. M. Nasrin Sulthana ${ }^{2}$ \\ ${ }^{1}$ Lecturer Fbms- Gulf College Oman, Sultanate of Oman \\ ${ }^{2}$ Assistant Professor Fbms - Gulf College Oman, Sultanate of Oman
}

*Corresponding Author: Ms. Fatima Amin, Lecturer Fbms- Gulf College Oman, Sultanate of Oman

\begin{abstract}
The purpose of this study is to examine the impact of financing source and its accessibility on the innovation and performance of firms. We have explored these relationships in the developing nations of South Asian region with 1504 firms of Bangladesh, 934 firms of Pakistan and 609 firms of Sri Lanka. World Bank Innovation Climate Surveys (enterprise surveys) for the manufacturing firms has used for the analysis. We used biprobit model for estimating the impact of financing sources and its accessibility on innovation. CobbDouglas model has been used to identify the impact of financing sources and its accessibility on firm's innovation and performance.
\end{abstract}

Keywords: Innovation; Financing Sources; Financial Obstacles; Labour Productivity; Product Innovation; Process Innovation

\section{INTRODUCTION}

In today's technological world innovation becomes a necessary component of virtually all businesses operating locally or internationally. Firms are increasingly moving towards innovations to capitalize on unique features of their production. Firms invest heavily in sustaining their competitive advantage through innovation in a long run. Innovation is a prevailing phenomenon whether it is a developed country or developing one. However, developing countries focus more on imitation than innovation. According to (Levin et al., 1987) imitation costs about 65-70\% of actual innovation cost.

Innovation is a complex phenomenon owing to involvement of many players in this process, ranging from intellectual capital of the innovative firm to its financial resources. Firms that are involved in innovation are facing many constraints. Lack of government support, less developed financial and capital markets increase the innovation costs for the firms (Gorodnichenko \& Schnitzer, 2010). Financing of innovation is a big challenge for the firms. This challenge, however, is more difficult to address properly for the firms operating in developing countries because of their poor financial structure.

\section{LiteratURE REVIEW}

\subsection{Innovation and Financing Sources}

A research study conducted by(Planes, Bardos, Sevestre, \& Avouyi-Dovi, 2001)compared the innovative and non-innovative firms by using the survey of Information and communication technologies conducted by SESSI for manufacturing industries and INSEE surveys for service sector. By taking the financial information and analysis of balance sheets, they observed a higher proportion of equity financing in the balance sheets of innovative firms as compared to non-innovative firms. Innovative firms without financial constraints show a strong financial structure in their balance sheet, and they have access to credit at lower rates(Planes et al., 2001). (Hall \& Lerner, 2009) reported that the innovative firms experience high cost of capital which is partly mitigated by venture capital.

\subsection{Firm Performance and Financing Sources}

(Osei-Assibey, 2010) conducted a research study on 5057 firms of Ghana in order to investigate the impact of nature and source of finance on the productivity of firms. By using the fifth round of Ghana 
Living Standard Survey, he found that the debt-financing boost the productivity of firm as compared to the use of internal finance and grants. He suggested that the access to formal finance increases the productivity of the firms. (Jayant R. Kale, 2012) found a positive concave relationship between financial leverage and labour productivity; they studied a panel data set of 16,482 firms for the period of 1975-2005. They concluded that at lower leverage levels, the employee's productivity is high but it reduces with the increase in debt portion of the capital structure.

World Bank Study (2008) states that the availability of external sources of finance increases innovation and dynamism across firms. Promotion of innovation for productivity growth requires investment in innovative projects, skilled labour, $R \& D$ activities, improvement of production process and the most important is access to finance (Wolf, 2007). (Gatti \& Love, 2006) conducted a research study on Bulgarian firms; they reported a positive association of access to finance and productivity. Similarly, agricultural industry has been explored by (Butler \& Cornaggia, 2011), and they showed a positive relation between productivity and credit at varying levels of access to finance.

\section{Methodology}

\subsection{Theoretical Model}

\subsubsection{Determinants of Innovation}

The Probit analysis has been used to evaluate the impact of independent variables on the binary dependent variable, i.e., the variable in the form of 0 or 1 . In our analysis, the innovation (both product and process innovation) is a binary dependent variable. Independent criterion variables include the financing sources and the financial obstacle. We also use some important determinants of innovation as control variables. The process and product innovation may be influenced by common unidentified factors. These factors may be statistically correlated and there may be great association in the unobserved features (captured by their respective disturbance terms) influencing both types of innovation. The biprobit model is then used to address the above stated phenomenon. Our model has the following form:

$$
\begin{aligned}
& \text { Inn }=\alpha+\beta_{1} \text { FinFixAst }+\beta_{2} \mathbf{Z}+\varepsilon \ldots \ldots \ldots(1) \\
& \text { Inn }=\alpha+\beta_{1} \text { Acctofin }+\beta_{2} \mathbf{Z}+\varepsilon \ldots \ldots \ldots . . .(2)
\end{aligned}
$$

Inn includes both product and process innovation. First model examines the impact of equity financing of fixed assets (FinFixAst) on the product and process innovation of firms. This variable is the mode of financing of fixed assets and is measured by debt and equity ratio. The second model investigates the impact of access to finance (Acctofin) on the product and process innovation. This is an obstacle faced by the firms for obtaining finance for investment in their operations. It includes overall financing needs of the firm, i.e., finance required for investment in fixed assets and current assets as well. It is measured in terms of financial costs associated with financial instruments. This cost includes high cost of capital, i.e., a hindrance towards firm's access to finance. Underwriter's fee is another financial obstacle that decreases availability of finance for firms. Lack of collateral also hampers firm's access to finance. Interest rate, fees and collateral obstacles to access to finance are measured on Likert-Scale from 4 for "very severe obstacle" to 0 for "no obstacle". The set of control variables $Z$ includes firm size, firm age, exports, imports, foreign owned technology and competition.

\subsubsection{Determinants of Firm Performance}

In order to find out the impact of financing sources of fixed assets and access to finance on performance of the firms, we use traditional Cobb-Douglas model augmented with our finance-related variables and has the following form:

$$
\begin{aligned}
& \operatorname{Pr}=\alpha+\beta_{1} \text { Fin.FixAsst }+\beta_{2} L+\beta_{3} N b v+\beta_{4} \mathbf{Y}+\varepsilon \ldots \ldots . .(3) \\
& \operatorname{Pr}=\alpha+\beta_{1} \text { Acctofin }+\beta_{2} L+\beta_{3} N b v+\beta_{4} \mathbf{Y}+\varepsilon \ldots \ldots \ldots . . .
\end{aligned}
$$


Pr stands for performance of the firms in terms of labour productivity. In addition to capital and labour, we include equity financing of fixed asset and access to finance variables as criterion variables and $\mathrm{Y}$ is a set of control variables including skills and education of employees, labour regulations and exports. $\boldsymbol{\varepsilon}$ is an error term.

\section{DATA AND DESCRIPTIVE STATISTICS}

\subsection{Data}

We use the World Bank Investment Climate Survey (enterprise survey) for the manufacturing firms, over two-digit industrial classifications, of three countries, i.e., Pakistan, Bangladesh and Sri Lanka. These surveys are conducted in 2006 for Pakistan and Bangladesh and in 2011 for Sri Lanka. ${ }^{1}$ The industries include foods, garments, leather, textiles, machinery and equipment, chemicals, electronics, non-metallic minerals and other manufacturing firms. Stratified random sampling using size, sector and geographical location as classification criteria has been used for selecting the sample. Some of the variables are used as they are measured in the survey; some are constructed according to the needs of this study. After cleaning for non-responses and potential outliers in the data, we selected 1504 firms from Bangladesh, 934 and 609 from Pakistan and Sri Lanka respectively.Table1reports the definitions and descriptions of the variables used in our analysis.

Table1: Description of variables

\begin{tabular}{|c|c|c|}
\hline Variables & Variables & Description \\
\hline EQFIX & Financing of Fixed Assets $^{\mathrm{a}}$ & $\%$ of equity used to finance fixed assets \\
\hline EXP & Exports (direct and indirect) & $\%$ of sales as direct and indirect exports \\
\hline IMP & Imports (foreign supplies) & $\%$ of firms purchases from foreign supplies \\
\hline SIZE & Firm size & Number of total employees \\
\hline LNBVE & Capital $^{\mathrm{b}}$ & Net book value to employees \\
\hline AGE & Firm age & Total years of operations \\
\hline $\mathrm{ACC}$ & Access to finance obstacle ${ }^{c}$ & $\begin{array}{l}\text { Dummy variable: } 1 \text { if access to finance is moderate, major } \\
\text { or very severe obstacle; } 0 \text { if it is no or minor obstacle }\end{array}$ \\
\hline COMP & Competition & $\begin{array}{l}\text { Dummy variable: } 1 \text { if there is high competition, } 0 \\
\text { otherwise }\end{array}$ \\
\hline FOTECH & Foreign owned technology & $\begin{array}{l}\text { Dummy variable: } 1 \text { if the firms use foreign owned } \\
\text { technology, } 0 \text { otherwise }\end{array}$ \\
\hline LABREG & Labour Regulation Obstacle & $\begin{array}{l}\text { Dummy variable: } 1 \text { if labour regulation is moderate, major } \\
\text { or very severe obstacle to the current operation of the firm, } \\
0 \text { if it is no or minor obstacle }\end{array}$ \\
\hline SKILEDU & $\begin{array}{l}\text { Skills and education of available } \\
\text { employees }\end{array}$ & $\begin{array}{l}\text { Dummy variable: } 1 \text { if skill and education of the available } \\
\text { employees is moderate, major or very severe obstacle, } 0 \text { if } \\
\text { it is no or minor obstacle }\end{array}$ \\
\hline PDINN & Product Innovation & $\begin{array}{l}\text { Dummy variable: } 1 \text { if the firm introduced new or } \\
\text { significantly improved products (in last three years), } 0 \\
\text { otherwise }\end{array}$ \\
\hline PRINN & Process Innovation & $\begin{array}{l}\text { Dummy variable: } 1 \text { if the firm introduced new or } \\
\text { significantly improved production processes (in last three } \\
\text { years), } 0 \text { otherwise }\end{array}$ \\
\hline LPROD & Labour productivity $^{\mathrm{d}}$ & Annual sales/ total employment \\
\hline
\end{tabular}

${ }^{a}$ We measure the financing sources by the proportion of fixed assets that are financed by equity and debt. (e.g., $60 \%$ of fixed asset is financed by equity and $40 \%$ by debt). Equity includes internal funds/retained earnings and issuance of new shares whereas debt includes borrowings from different sources.

${ }^{\mathrm{b}}$ Capital is measured in terms of net book value with respect to employees. Net book value is measured as the net book value of the firm's assets after depreciation.

${ }^{c}$ Access to finance obstacle is measured to rate the financial obstacles (availability of finance and the cost (interest rate, fees and collateral requirements)) faced by the firms.

${ }^{\mathrm{d}}$ Labour productivity is taken as performance indicator, and it is the sales per employee. Sales are given in each country's currency; we standardize the annual sales of three countries with respect to the U.S dollar.

${ }^{1}$ Details of the surveys can be found at www.enterprisesurveys.org 


\subsection{Descriptive Statistics}

Table 2 shows the summary statistics of continuous variables. It is observed that firms use approximately $80 \%$ equity financing for investment in fixed assets in Bangladesh and Pakistan, while in case of Sri Lanka this percentage is 57\%. This means that the pattern of financing across two counries (Bangladesh and Pakistan) is almost the same, but quite different in Sri Lanka. From this statistics, it can be stated that in developing countries more than $50 \%$ equity financing is used for investment in fixed assets.

Table2: Summary Statistics of Continuous Variables

\begin{tabular}{|l|l|l|l|l|l|l|}
\hline \multirow{2}{*}{ Variables } & \multicolumn{2}{c|}{ Bangladesh } & \multicolumn{2}{c|}{ Pakistan } & \multicolumn{2}{c|}{ Sri Lanka } \\
\cline { 2 - 7 } & \multicolumn{1}{|c|}{ Mean } & \multicolumn{1}{c|}{ S.D } & \multicolumn{1}{c|}{ Mean } & \multicolumn{1}{c|}{ S.D } & \multicolumn{1}{c|}{ Mean } & \multicolumn{1}{c|}{ S.D } \\
\hline Sales per emp. (in thousands) & 7.545 & 26.482 & 25.610 & 145.086 & 20.835 & 62.865 \\
\hline EQFIX (\%) & 78.4722 & 35.157 & 79.937 & 36.262 & 56.528 & 40.542 \\
\hline SIZE & 258.499 & 572.98 & 103.95 & 453.3 & 112.556 & 380.93 \\
\hline AGE (years) & 16.8117 & 13.577 & 20.137 & 13.42 & 23.9155 & 20.667 \\
\hline EXP (\%) & 29.083 & 44.46 & 10.9 & 28.807 & 14.1511 & 33.183 \\
\hline IMP (\%) & 34.9748 & 39.87 & 11.765 & 25.484 & 11.3463 & 27.293 \\
\hline Net book val. per emp. (in thousands) & 5.592 & 18.742 & 15.509 & 224.140 & 8.286 & 18.783 \\
\hline
\end{tabular}

Pakistan is depicting the highest productivity level with the lowest firm size as compared to the firms of Bangladesh and Sri Lanka. One of the reasons of this highest labour productivity in Pakistan might be the high percentage of fixed assets per employee. Pakistani firms are showing on average highest net book value, i.e., $\$ 15,509$ as compared to $\$ 8,286$ for Sri Lankan firms and $\$ 5,592$ for Bangladeshi firms. The summary statistics of dummy variables used in this study are reported in Table 3.

Table3: Summary Statistics of Dummy Variables

\begin{tabular}{|l|l|l|l|}
\hline \multirow{2}{*}{ Variables } & \multicolumn{1}{|c|}{ Bangladesh } & \multicolumn{1}{c|}{ Pakistan } & Sri Lanka \\
\cline { 2 - 4 } & $\%$ & $\%$ & $\%$ \\
\hline PRINN & 44.96 & 9.6 & 43.49 \\
\hline PDINN & 33.14 & 12.32 & 31.03 \\
\hline ACC & 51.5 & 41.81 & 50.25 \\
\hline
\end{tabular}

Bangladeshi firms are slightly more innovators with $55.96 \%$ process and $33.14 \%$ product innovators than Sri Lankan firms (43.49\% process innovators and 31.03\% product innovators), but the difference is large for Pakistani firms with $9.6 \%$ process innovators and $12.32 \%$ product innovators. Pakistan is showing the least innovative behaviour as compared to other developing countries in our analysis. Approximately $50 \%$ of Bangladeshi and Sri Lankan firms are facing access to finance obstacle, and $42 \%$ firms in Pakistan are facing this problem.

\section{DATA ANALYSiS}

\subsection{Impact of Financing Sources on Innovation}

As discussed, to find out the impact of financing sources on innovation, we use the debt and equity percentages used to finance fixed assets as independent variable and product and process innovation as dependent variables along with a set of control variables. We use biprobit model to find out the influence of financing sources on product and process innovation. The results are shown in Table 4.

Table 4: Biprobit Model: Effect of financing sources on product and process innovation

\begin{tabular}{|c|c|c|}
\hline & \multicolumn{2}{|c|}{ Dependent Variables } \\
\hline & PRINN & PDINN \\
\hline EQFIX & $\begin{array}{l}0.003^{* * *} \\
(0.002)\end{array}$ & $\begin{array}{l}0.006 * * * \\
(0.002)\end{array}$ \\
\hline EXP & $\begin{array}{l}-0.002 \\
(0.002)\end{array}$ & $\begin{array}{l}-0.006 * * * \\
(0.002)\end{array}$ \\
\hline AGE & $\begin{array}{l}-0.002 \\
(0.004)\end{array}$ & $\begin{array}{l}-0.006 \\
(0.004)\end{array}$ \\
\hline SIZE & $\begin{array}{l}0.24 * * * \\
(0.059) \\
\end{array}$ & $\begin{array}{l}0.232 * * * \\
(0.059)\end{array}$ \\
\hline COMP & $\begin{array}{l}0.075 \\
(0.214) \\
\end{array}$ & $\begin{array}{l}-0.211 \\
(0.216) \\
\end{array}$ \\
\hline
\end{tabular}




\begin{tabular}{|l|l|l|}
\hline \multicolumn{2}{|l|}{} \\
\hline IMP & $0.005^{* * *}$ & $0.005^{* * *}$ \\
& $(0.002)$ & $(0.002)$ \\
\hline FOTECH & $0.461^{* *}$ & $0.68 * * *$ \\
& $(0.215)$ & $(0.207)$ \\
\hline Intercept & $-0.821^{* *}$ & $-0.755^{* *}$ \\
& $(0.345)$ & $(0.352)$ \\
\hline No. of obs. & 469 & \multicolumn{2}{|l|}{} \\
\hline Model Fit & $140.13^{* * *}$ & $17.36^{* * *}$ \\
\hline Industry significance & $12.04 *$ & \\
\hline
\end{tabular}

$* * * 1 \%$ significance level, $* * 5 \%$ significance level, $* 10 \%$ significance level

Note: Industry and country dummies are included.

Industry significance in both models, although for process innovation significance is achieved only at $10 \%$ level, shows that industry-specific differences play an important role in both innovation types. The test for model fit shows the model as a whole is a good model. Recall that the statistics show that firms use more than $50 \%$ of equity financing 2 for investment in fixed assets. The estimates show a highly positive impact of equity financing of fixed assets on both product and process innovation. This means that the equity financing enhances the firm's probability to innovate. Innovation requires heavy investments and has uncertain outcomes. Therefore, it might be better to use equity for the financing of fixed assets in innovative firms. There are many reasons why the equity financing enhances innovativeness of the firms. It includes lack of collateral requirements, lack of interest payments during progress of the projects and no fear of credit rationing. As the innovative projects are usually long-term and uncertain in nature and require heavy investments, equity financing might be favourable for innovative firms. Our finding of equity financing is consistent with Brown et al.'s(2009) findings that firms use equity sources to finance their R\&D expenditure. Our results suggest that an increase in the labour force helps the firms to innovate more. If the innovative tasks are divided across a large labour force, they can perform better and their contributions help the firms to complete their innovative projects within time(Hoegl et al., 2008). Competition shows a positive impact on process innovation but a negative impact on product innovation, although both are insignificant.

\subsection{Impact of Financing Sources and Access to Finance Obstacle on Productivity}

To estimate the effect of main variables of this study, i.e., financing sources and access to finance obstacle on productivity of the firms, we use well-known Cobb- Douglas model. The results are reported in Table 6.Our model includes the capital and labour inputs along with our main variables and a set of control variables. Capital is measured by the net book value to total employees, and the variable for labour is measured by the total number of temporary and permanent employees. Our model for productivity involves two equations. In the first equation, we identify the influence of equity financing of fixed assets (keeping the debt financing as a reference) on the labour productivity of the firms. In the second equation, we observe the impact of access to finance obstacle (as moderate to severe obstacle keeping the minor obstacle or no obstacle as a reference) on the labour productivity of the firms.

Table5: Cobb-Douglas Model; Impact of financing sources and access to finance obstacle on the labour productivity of firms

\begin{tabular}{|l|l|l|}
\hline \multirow{2}{*}{ EQFIX } & \multicolumn{2}{|l|}{ Dependent Variable: LPROD } \\
\cline { 2 - 3 } & Equation (3) & Equation (4) \\
\hline ACC & & $\begin{array}{l}0.001 \\
(0.001)\end{array}$ \\
& & \\
\hline LNBVE & $-0.112^{* *}$ & \\
\hline SIZE & $(0.054)$ & $0.331 * * *$ \\
& $0.272^{* * *}$ & $(0.023)$ \\
\hline
\end{tabular}

${ }^{2}$ Financing sources are measured in terms of debt and equity proportion used by the firms to finance their fixed assets. This variable is in the form of percentage. We insert equity proportion in the analysis and keep the debt proportion as a reference. 


\begin{tabular}{|c|c|c|}
\hline & $(0.022)$ & $(0.030)$ \\
\hline SKILEDU & $\begin{array}{l}0.192 * * * \\
(0.057)\end{array}$ & $\begin{array}{l}0.042 \\
(0.076)\end{array}$ \\
\hline LABREG & $\begin{array}{l}0.047 \\
(0.069)\end{array}$ & $\begin{array}{l}0.012 \\
(0.085)\end{array}$ \\
\hline EXP & $\begin{array}{l}0.004 * * * \\
(0.001)\end{array}$ & $\begin{array}{l}0.005 * * * \\
(0.001)\end{array}$ \\
\hline Intercept & $\begin{array}{l}5.927 * * * \\
(0.163)\end{array}$ & $\begin{array}{l}5.265 * * * \\
(0.267)\end{array}$ \\
\hline No. of obs. & 1962 & 847 \\
\hline Model Fit & $56.10 * * *$ & $43.98 * * *$ \\
\hline R-Squared & 0.287 & 0.425 \\
\hline Industry significance & $6.35 * * *$ & $5.84 * * *$ \\
\hline
\end{tabular}

$* * * 1 \%$ significance level, $* * 5 \%$ significance level, $* 10 \%$ significance level

Note: Industry and country dummies are included.

For both equation 3 and 4, industry significance shows that different industries have different contributions towards labour productivity. The statistical analysis based upon the equation 3 depicts that if the firm is facing from moderate to very severe access to finance obstacle as compared to minor or no obstacle, its labour productivity will be decreased. The Access to finance obstacle variable has a significant, negative influence on the labour productivity of the firms. When the firms face absence/ unavailability of finance and/or high costs of finance, they will not be able to pay the salaries properly and will not offer incentives to their labour force in order to enhance their productivity. Access to finance is also important for taking care of other operational cost of the firm. Therefore, smooth accessibility to finance is highly needed to enhance labour productivity.

In case of the equation 4, equity financing of fixed assets have an insignificant, positive influence on the labour productivity of the firm. This means that equity financing does not have any impact on labour productivity. It suggests that the financing decisions do not affect labour productivity of the firms. The labour is indifferent of the financing sources used by the firms to invest in fixed assets.

All the other independent variables have significant, positive impact on the labour productivity except the labour regulations obstacle; it has a positive but insignificant influence on productivity. The traditional inputs of Cobb- Douglas model have a significant, positive impact on the labour productivity. This means that an increase in the fixed assets (property, plant and equipment) of the firm increases the labour productivity, as the firms would be able to produce more and meet their targets within time by using required fixed assets. Similarly, an increase in labour force enhances the firm's labour productivity. Labour force enhances the firms potential to produce more in order to meet market requirements. The results of labour regulations obstacle and skills and education obstacles are insignificant except a positive relationship between SKILEDU and LPROD in case of equation 3. The likely interpretation is that labour laws are not effectively implemented in developing countries and companies run their business regardless of these laws. The reason for the results of SKILEDU, especially in case of equation 3, might be that in developing nations the educated and skilled labour is not available. The literacy rate in these countries is very low and mostly the labour is undergraduate and of graduate level. Therefore, the skills and education of employees is an obstacle for the current operations of the firm, but keeping in view this scarcity the firms try to resolve this obstacle by training of the employees.

\section{CONCLUSiON}

This study is carried out to investigate the relationship of financing modes and access to finance with innovation and labour productivity. We observe a clear pattern of financing across Pakistan, Bangladesh and Sri Lanka. We find that firms used more than $50 \%$ of equity sources to finance their fixed assets in all three countries. We can argue that equity financing is always the major portion of firm's capital structure either it is a developed or developing nation. In our analysis the role of financing sources of fixed assets on the decision of firms to involve in product and process innovation. Innovation is a long-term, on-going process, and assets required for innovative projects are arguably fixed assets. We give the empirical evidence that in developing nations of South Asian region equity financing of fixed assets enhances the firm's probability to engage in product and 
process innovation. Therefore, it is evident from this study that similar to the developed nations equity financing is also an important source of financing of innovative projects in the developing nations. We also explore the impact of financing sources on the labour productivity of the firms, and it is shown that equity financing of fixed assets does not have any impacton labour productivity. It shows that financing decisions do not have any influence on the labour productivity of firms in developing nations.

The reasons for this result might be that the firms would not be able to offer bonus and other incentives to their labour force because of hindrance in the access to finance. The firms will not be able to adopt the strategies to improve their labour productivity, especially in developing nations, because labour force is influenced by monetary benefits and incentives. They could produce more if they are satisfied by their wages and incentives. In addition, companies need finance to run their operational activities needed for manufacturing and thereby enhancing labour productivity.

\section{REFERENCES}

[1] Butler, A. W., \& Cornaggia, J. (2011). Does access to external finance improve productivity? Evidence from a natural experiment. Journal of Financial Economics, 99(1), 184-203.

[2] Gatti, R., \& Love, I. (2006). Does access to credit improve productivity? Evidence from Bulgarian firms (Policy Research Working Paper Series No. 3921). The World Bank.

[3] Gorodnichenko, Y., \& Schnitzer, M. (2010). Financial constraints and innovation: Why poor countries don't catch up (Working Paper No. 15792). National Bureau of Economic Research.

[4] Hall, B. H., \& Lerner, J. (2009). The Financing of R\&D and Innovation (Working Paper No. 15325). National Bureau of Economic Research.

[5] Hoegl, M., Gibbert, M., \& Mazursky, D. (2008). Financial constraints in innovation projects: When is less more? Research Policy, 37(8), 1382-1391.

[6] Hyytinen, A., \& Toivanen, O. (2005). Do financial constraints hold back innovation and growth?: Evidence on the role of public policy. Research Policy, 34(9), 1385-1403.

[7] Levin, R. C., Klevorick, A. K., Nelson, R. R., Winter, S. G., Gilbert, R., \& Griliches, Z. (1987). Appropriating the Returns from Industrial Research and Development. Brookings Papers on Economic Activity, 1987(3), 783.

[8] Mulkay, B., Hall, B. H., \& Mairesse, J. (2001). Firm Level Investment and R\&D in France and the United States: A Comparison. In D. Bundesbank (Ed.), Investing Today for the World of Tomorrow (pp. 229273). Springer Berlin Heidelberg.

[9] Osei-Assibey, E. (2010). Does Source of Finance Matter for Microenterprise Productivity Growth in Ghana? (SSRN Scholarly Paper No. ID 1611559). Rochester, NY: Social Science Research Network.

[10] Planes, B., Bardos, M., Sevestre, P., \& Avouyi-Dovi, S. (2001). INNOVATION: FINANCING AND FINANCING CONSTRAINTS1.

[11] Ughetto, E. (2009). Industrial districts and financial constraints to innovation. International Review of Applied Economics, 23(5), 597-624.

[12] Wolf, S. (2007). Encouraging innovation for productivity growth in Africa (Working paper).

Citation: Ms. Fatima Amin, Dr. M. Nasrin Sulthana. “ Impact of Financing Sources on Innovation and Firm Productivity: Evidence from South Asia" International Journal of Managerial Studies and Research (IJMSR), vol 7, no.7, 2019, pp. 7-13. doi: http://dx.doi.org/10.20431/2349-0349. 0707002.

Copyright: (C) 2019 Authors. This is an open-access article distributed under the terms of the Creative Commons Attribution License, which permits unrestricted use, distribution, and reproduction in any medium, provided the original author and source are credited. 